Acta vet. scand. $1978,19,601-603$.

Brief Communication

\title{
IMMUNOGLOBULINS IN BOVINE OSTERTAGIASIS
}

Lowered albumin levels with normal or slightly elevated $\gamma$ globulin levels are well known features of various gastro-intestinal disorders in cattle. Thus, this picture is a prominent finding in clinical ostertagiasis, where hypercatabolism of both albumin (Nielsen 1966) and IgG (Nansen 1970) has been demonstrated. The hypercatabolism is explained by gastric loss, and evidence suggests that this takes place as a non-selective loss of protein through the hyperplastic abomasal wall (Murray 1969). The albumin hypercatabolism is not compensated for by an increased synthesis, and thus leads to hypoalbuminaemia also during part of the non-diarrhoeal phase. The IgG hypercatabolism, on the other hand, is compensated for by increased synthesis, which may lead to elevated serum IgG levels, especially in phases without diarrhoea. There seems to be no comparative data available for IgG-1, IgG-2, IgM, and IgA levels in ostertagiasis. The purpose of the present study was to analyse the influence of ostertagiasis on the serum levels of immunoglobulins, albumin and total protein in young cattle. The study comprised two groups of randomly selected Red Danish calves, approx. $1 / 2$ year old. Half the calves (Group A) grazed the same paddock from May to late September and were exposed to heavy infection from August onwards as evidenced by high herbage larval counts, high faecal egg counts, and elevated serum pepsinogen levels (see Table 1). Most of the calves were clinically affected, and in the last part of August and September some had profuse diarrhoea. The other calves (Group B) were moved in mid July to a paddock not grazed earlier that season. Accordingly, these calves were exposed to only a relatively low pasture infection in the second half of the grazing season. None of them showed clinical signs, and pepsinogen levels were only slightly elevated (Table 1).

Blood samples obtained at the time of turning out and again 18 weeks later, i.e. in mid September, were analysed. After clotting at room temperature, serum was removed from the samples and stored at minus $20^{\circ} \mathrm{C}$ until analysed. The concentrations of 
T a b le 1. Serum levels (mean $\pm \mathrm{s}$ ) of immunoglobulins (Ig), albumin, total protein and pepsinogen in two groups of calves, one heavily (A), the other slightly

(B) infected with Ostertagia ostertagi during the grazing season. The mean increases for the two groups were compared by means of student's t-test.

\begin{tabular}{|c|c|c|c|c|c|c|c|c|c|c|}
\hline \multirow[b]{2}{*}{$\begin{array}{l}\text { Total protein } \\
(\mathrm{g} / 100 \mathrm{ml})\end{array}$} & \multicolumn{2}{|c|}{ Group $^{1}$} & \multicolumn{2}{|c|}{$10 / 5$} & \multicolumn{2}{|r|}{$13 / 9$} & \multicolumn{3}{|c|}{$\begin{array}{c}\text { Difference } \\
(13 / 9-10 / 5)\end{array}$} & \multirow{2}{*}{$\begin{array}{c}\mathrm{t} \\
0.54\end{array}$} \\
\hline & $\begin{array}{l}\mathrm{A} \\
\mathrm{B}\end{array}$ & $\begin{array}{l}6.38 \\
6.38\end{array}$ & & $\begin{array}{l}0.32 \\
0.29\end{array}$ & $\begin{array}{l}6.48 \pm \\
6.33 \pm\end{array}$ & $\begin{array}{l}0.66 \\
0.34\end{array}$ & $\begin{array}{r}0.09 \\
-0.06\end{array}$ & $\begin{array}{l} \pm \\
\pm\end{array}$ & $\begin{array}{l}0.82 \\
0.40\end{array}$ & \\
\hline $\begin{array}{l}\text { Albumin } \\
(\mathrm{g} / 100 \mathrm{ml})\end{array}$ & $\begin{array}{l}\mathrm{A} \\
\mathrm{B}\end{array}$ & $\begin{array}{l}3.23 \\
3.08\end{array}$ & & $\begin{array}{l}0.19 \\
0.17\end{array}$ & $\begin{array}{l}2.88 \pm \\
3.32 \pm\end{array}$ & $\begin{array}{l}0.38 \\
0.32\end{array}$ & $\begin{array}{r}-0.35 \\
0.23\end{array}$ & \pm & $\begin{array}{l}0.45 \\
0.32\end{array}$ & $3.53^{* *}$ \\
\hline $\begin{array}{l}\text { IgG-1 } \\
(\mathrm{mg} / 100 \mathrm{ml})\end{array}$ & $\begin{array}{l}\mathrm{A} \\
\mathrm{B}\end{array}$ & $\begin{array}{l}1349.2 \\
1597.1\end{array}$ & $\begin{array}{l} \pm 2 \\
\pm 2\end{array}$ & $\begin{array}{l}57.0 \\
292.5\end{array}$ & $\begin{array}{l}2442.7 \\
1732.2\end{array}$ & $\begin{array}{l} \pm 475.7 \\
\pm 291.6\end{array}$ & $\begin{array}{r}1093.2 \\
135.1\end{array}$ & \pm & $\begin{array}{l}528.4 \\
366.7\end{array}$ & $5.01 * *$ \\
\hline $\begin{array}{l}\text { IgG-2 } \\
(\mathrm{mg} / 100 \mathrm{ml})\end{array}$ & $\begin{array}{l}\mathrm{A} \\
\mathrm{B}\end{array}$ & $\begin{array}{l}89.7 \\
96.4\end{array}$ & \pm & $\begin{array}{l}30.2 \\
31.4\end{array}$ & $\begin{array}{l}69.8 \pm \\
88.5 \pm\end{array}$ & $\begin{array}{l} \pm 18.0 \\
\pm \quad 28.5\end{array}$ & $\begin{array}{r}-19.9 \\
-6.9\end{array}$ & & $\begin{array}{l}28.6 \\
15.2\end{array}$ & 1.29 \\
\hline $\begin{array}{l}\mathrm{IgM} \\
(\mathrm{mg} / 100 \mathrm{ml})\end{array}$ & $\begin{array}{l}\mathrm{A} \\
\mathrm{B}\end{array}$ & $\begin{array}{l}488.4 \\
498.7\end{array}$ & $\begin{array}{l} \pm 1 \\
\pm 1\end{array}$ & $\begin{array}{l}70.3 \\
33.3\end{array}$ & $\begin{array}{l}740.7 \text { 士 } \\
567.7\end{array}$ & $\begin{array}{l} \pm 166.3 \\
\pm 213.5\end{array}$ & $\begin{array}{r}252.2 \\
68.9\end{array}$ & \pm & $\begin{array}{l}59.3 \\
149.7\end{array}$ & $2.84^{* *}$ \\
\hline $\begin{array}{l}\text { IgA } \\
(\mathrm{mg} / 100 \mathrm{ml})\end{array}$ & $\begin{array}{l}\mathrm{A} \\
\mathrm{B}\end{array}$ & $\begin{array}{l}14.7 \\
14.3\end{array}$ & \pm & $\begin{array}{r}5.2 \\
11.7\end{array}$ & $\begin{array}{l}23.9 \pm \\
13.5 \pm\end{array}$ & $\begin{array}{rr} \pm & 11.5 \\
\pm \quad 5.9\end{array}$ & $\begin{array}{r}9.2 \\
-0.7\end{array}$ & & $\begin{array}{r}10.6 \\
9.1\end{array}$ & $2.38^{*}$ \\
\hline $\begin{array}{l}\text { Pepsinogen } \\
\text { (tyrosine } \\
\text { units per 1) }\end{array}$ & $\begin{array}{l}\mathrm{A} \\
\mathrm{B}\end{array}$ & $\begin{array}{l}0.3 \\
0.3\end{array}$ & $\begin{array}{l} \pm \\
\pm\end{array}$ & $\begin{array}{l}0.15 \\
0.08\end{array}$ & $\begin{array}{l}4.3 \pm \\
1.7 \pm\end{array}$ & $\begin{array}{ll} \pm & 1.58 \\
\pm & 0.78\end{array}$ & $\begin{array}{l}4.0 \\
1.4\end{array}$ & \pm & $\begin{array}{l}1.58 \\
0.80\end{array}$ & $4.92^{\cdots} \cdots$ \\
\hline
\end{tabular}

${ }^{*} \mathrm{P}<0.05 ;{ }^{* \star} \mathrm{P}<0.01 ;{ }^{* *} \mathrm{P}<0.001$.

$1 \mathrm{~A}: \mathrm{n}=12 . \mathrm{B}: \mathrm{n}=11$.

immunoglobulins (IgG-1, IgG-2, IgM and IgA) were determined by the single radial immunodiffusion technique with a bovine serum pool as standard (Jensen 1978). Serum albumin was determined according to Nisbet et al. (1973) and serum pepsinogen according to Ross et al. (1967). Total serum protein was determined by the biuret method with a kit from $\mathrm{Fa}$ Boehringer, Mannheim.

As seen from Table 1, the serum albumin level was significantly lowered in the heavily infected group as compared with the group of slightly infected animals. On the other hand, there was a marked and highly significant rise in IgG-1 in the heavily infected animals, and also the IgM and IgA levels were significantly higher in these than in the slightly infected animals. For IgG-2 there was a fall in the mean serum levels for both groups of animals, but with no significant difference between the groups. The fall in serum IgG-2 levels contrasts with the increase normally occurring in the young (Jensen \& Christensen 1975). The results of the present study show that ostertagiasis acquired on pasture is associated with a fall in serum albumin, and with a rise in immunoglobulins other than IgG-2. This reflects different metabolic 
responses to the infection. On the assumption that a bulk loss of serum proteins is likely to occur it may be justifiable to conclude that the parasitic infection accelerates synthesis of IgG-1, IgM and IgA, but not - or only to a less extent - of IgG-2. This contrasts with the responce to pyogenic bacterial infections, where synthesis of IgG-2 is usually raised (Nansen).

\section{ACKNOWLEDGEMENT}

The authors are indebted to Mrs. B. Lüders Jensen for her very skilful technical assistance.

\section{P. Thode Jensen}

The State Veterinary Serum Laboratory, Copenhagen, Denmark, and

\section{P. Nansen}

The Institute of Hygiene and Microbiology,

Royal Veterinary and Agricultural University, Copenhagen, Denmark.

\section{REFERENCES}

Jensen, P. T.: Quantitative studies on immunoglibulins, albumin and total protein in serum from young normal calves. Nord. Vet.Med. $1978,30,145-154$.

Jensen, P. T. \& K. Christensen: Genetic analysis of the serum level of IgG-2 and total protein in Red Danish cattle. J. Anim. Sci. 1975, $40,392-396$.

Murray, M.: Structural changes in bovine ostertagiasis associated with increased permeability of the bowel wall to macromolecules. Gastroenterology $1969,56,763-772$.

Nansen, P.: Metabolism of Bovine Immunoglobulin-G. A Clinical and Pathophysiological Study. Thesis, Munksgaard, Copenhagen 1970 .

Nielsen, K.: Gastrointestinal Protein Loss in Cattle. A Clinical and Pathophysiological Study. Thesis, Carl Fr. Mortensen, Copenhagen 1966.

Nisbet, J., A. Jarvis \& A. Fenton: Measurement of human serum albumin with bromcresol green. A simultaneous comparison of two methods on the SMA $12 / 60$. Clin. Chim. Acta $1973,45,189-191$.

Ross, J. G., D. A. Prucell, C. Dow \& J. R. Todd: Experimental infection of calves with Trichostrongylus axei; the course of development of infection and lesions in low level infections. Res. Vet. Sci. $1967,8,201-206$.

(Received November 9, 1978).

Reprints may be requested from: P. Thode Jensen, The State Veterinary Serum Laboratory, Bülowsvej 27, DK-1870 Copenhagen V, Denmark. 